International Journal of Current Aspects in Finance, Banking and Accounting, Volume 3, Issue 1, 2021 PP 9-20, ISSN 2707-8035

[iJCAB

\title{
Digital Financial Services and Financial Performance of Savings and Credit Cooperative Societies in Kakamega County, Kenya
}

\author{
Kizito Simiyu Wanyonyi, Ngaba Dominic
}

\author{
Department of Accounting and Finance, Kenyatta University, Kenya
}

\begin{abstract}
Savings and Credit Co-operative Societies (Saccos) in Kenya have realized a tremendous growth in the subsector and are investing huge amount of their scarce financial resources in digital technology to enhance services delivery and offer a wide variety of products and services range, increased membership mobilization and size, ensure better structure and effective financial performance. Digital financial Services as used in the Saccos industry is because of Information Communication Technology revolution commonly referred to as digital commerce. Many Saccos are steadily changing from manual banking system of operations to providing digital Financial (e-banking) services that include internet banking, M-banking and Automated Teller machine support. The adoption of digital financial Services by the Saccos is a strategic attempt to deal with increased cutthroat competition from traditional banking institutions and non-banking financial institutions, to cut costs and add value to their services in order to optimize benefits to the shareholders. Even though Saccos have rapidly adopted digital financial services to provide services, and that they drive a huge section of the financial sector savings of the economy, they have experienced various challenges such as uncertainty and risk due to digital financial services. The study sought to establish the influence of digital financial services on the financial performance of SACCOs in Kakamega County, Kenya. The specific objectives was to determine the effect of the mobile banking, internet banking, use of credit cards and digital funds transfer on the financial performance of SACCOs in Kakamega County, Kenya. The research was guided by three theories of innovation and technology: Diffusion of Innovation Theory, The Theory of Task-Technology Fit Theory and the Technological context, Organizational context and Environmental context Theory. The study used a descriptive research design. The population of study were staff at the three SACCOs operating in Kakamega County. This consisted of 162 respondents who are the staff of the SACCOs. A sample of 49 respondents was taken which forms $30 \%$ of the target population which shall be evenly spread across the three SACCOs. The primary data was collected by use of self-administered semi-structured questionnaire. Collected data was analyzed through descriptive and inferential statistics by the use of SPSS. Findings were presented by use of tables, frequencies, percentages, means and standard deviation. The study found that the financial performance of the SACCOs was significantly influenced by the digital financial services instituted by the SACCO managements. They demonstrated to have reliable mobile banking system where most of their customers had enrolled on the mobile banking platform and most of customer queries and updates were sorted via the mobile platform. Given the limitations and findings of this study, the researcher recommends that since there exists a positive relationship between digital financial services and bank performance and that e-banking has brought services closer to bank customer's hence improving banking industry performance, SACCOs must also enhance the dynamics of the sector and embrace digital banking fully and extensively. Mobile banking faces various challenges among them being, system delays by the mobile money transfer service providers, slow processing of transactions, high transactions costs, limit on the amount of money that can be withdrawn in a day and fraud.
\end{abstract}


International Journal of Current Aspects in Finance, Banking and Accounting, Volume 3, Issue 1, 2021 PP 9-20, ISSN 2707-8035

iJCAB

Key Words: Digital Financial Services, Financial Performance, Financial Resources Mobilization

DOI: $10.35942 /$ ijcfa.v3i1.177

\section{Cite this Article:}

Wanyonyi, K., \& Ngaba, D. (2021). Digital Financial Services and Financial Performance of Savings and Credit Cooperative Societies in Kakamega County, Kenya. International Journal of Current Aspects in Finance, Banking and Accounting, 3(1), 9-20. https://doi.org/10.35942/ijcfa.v3i1.177

\section{Introduction}

Over the years and especially since the year 2000, tremendous change has occurred in the financial sector most triggered by inventions in the world of technology, financial system, legal frameworks and customer needs and preferences. Most of the big banks and SACCOs that used to adopt digital innovations in the past to meet the changing customer needs have either rebranded; and the current sector giants are only a decade old. This reflects the role of digital banking services in ensuring firm survival, competitiveness, and optimal financial performance from increased financial inclusion at the backdrop of the global financial crisis (Kimani, 2016). According to Korir (2014) the major impetus for digital strategies such as mobile banking and online banking has been competition, globalization, deregulation and technological advancement. The survival in this sector has been majorly driven by frequent and constant adoption of digital banking services to increase financial performance. With these digital practices, financial sector players have significantly enhanced their service quality to meet the changing needs of customer, increased financial inclusion hence their survival and profitability. Given the adoption of such innovations is capital intensive, and its failure rate is very high, banks and SACCOs greatly struggle in designing and implementing the best suited digital banking services in their markets (Lawrence, 2010)

Savings and Credit Co-operative Societies (Saccos) in Kenya have realized a tremendous growth in the subsector and are investing huge amount of their scarce financial resources in digital technology (IT) to enhance services delivery and offer a wide variety of products and services range, increased membership mobilization and size, ensure better structure and effective financial performance (Koduk, 2015). Digital banking as used in the Saccos industry is as a result of Information Communication Technology (ICT) revolution commonly referred to as digital commerce (Ovia, 2001). Many Saccos are steadily changing from manual banking system of operations to providing digital banking (e-banking) services that include internet banking, Mbanking and Automated Teller machine support (ATM). Mouawad and Kleiner (1996) posit that the adoption of digital banking by the Saccos is a strategic attempt to deal with increased cut throat competition from traditional banking institutions and non-banking financial institutions, to cut costs and add value to their services in order to optimize benefits to the shareholders. Even though there is a rapid adoption of digital banking taking place in Saccos industry in Kenya, it is coming much later relative to the use of digital banking in the traditional banking institutions. The Saccos adopting digital banking are applauded by the citizens and the government of Kenya since digital banking is considered a way of improving productivity and a means of gaining competitive advantage (Oyugi, 2014). Saccos are also considered to have a vital economic value in terms of productivity and growth, employment generation and dynamics, community development, equity promotion or innovation. From this perspective, better financial performance of Saccos enhances the effectiveness and sustainability of Saccos (Aduda \& Kingoo, 2012). It is therefore envisaged 
International Journal of Current Aspects in Finance, Banking and Accounting, Volume 3, Issue 1, 2021 PP 9-20, ISSN 2707-8035

\section{IICAB}

that huge benefits that include effective service delivery, cost reduction and accessibility will accrue to the many clients, firms and regulators that adopt digital banking (Koduk, 2015). While digital banking has efficiently facilitated tasks of Saccos and made services less expensive, investment in automation consumer huge rare financial resources (Atavachi, 2015). Therefore, a sound analysis of costs and risks associated with digital banking is needed to avoid harm on Sacco's financial performance.

In Kenya Saccos are registered under the Sacco Societies Act (2008). Under the Act (2008), Saccos are licensed, regulated and promoted by the Sacco Societies Regulatory Authority (SASRA). The Act (2008) provides minimum requirements for operation and prudent standards necessary for Saccos that take deposit to minimize risk and ensure stability in funds of the Saccos. The Saccos are classified into those Saccos that take deposit (DTSs) and those that do not take deposit. Saccos that take deposit give members savings and credit services in form of basic banking services. Such Saccos accept deposit, provide payment services and operate quasi banking services known as Front Office Services Activities (FOSA). FOSAs are part of Saccos' e-banking activities which are licensed by SASRA and are aimed at improving customer services, cutting costs and ensuring effective operation of Saccos (SASRA Report 2014). As a norm, Saccos begin as non-Deposit Taking Saccos and eventually grow to deposit taking Saccos where they provide a variety of financial services to their members (Kenya Financial Stability Report, 2014).

The study aimed at assessing the relationship between digital banking and financial performance of Deposit Taking Savings and Credit Co-operative Societies in Kakamega County, Kenya. The study used three theories: Rogers's Innovation Diffusion Theory, Task-Technology Fit Theory and Technological context, Organizational context and Environmental context theory to explain and understand the underlying factors in adoption of innovation such as digital banking by Saccos. Savings and Credit Cooperative Societies in western Kenya are growing and showing improvement in performance in the region. However, the greatest development has been the adoption of digital banking services in their operations, a step that has seen Saccos enhance operational efficiency and service delivery to clients, (Afubwa et al., 2013). Atavachi (2013) notes that most Saccos in Kenya are investing their scarce financial resources in digital banking services to enhance performance. This gives them a competitive advantage in the Saccos subsector in Kenya.

Majority of SACCOs' growth in Kenya and more especially in Western Kenya is dismal. Many of them still do not have FOSA services. How to strategize for financial innovation basing on the available resources to attain growth has become a great challenge (SASRA, 2015). There is clear inadequacy of financial innovation among SACCOs in Kenya. More than $81 \%$ of Kenyans rely on SACCO's to access financial services (Mwanahawa, 2012). However, the use of SACCOs by Kenyans as a financial service provider has been declining over the last five years. The decline has been from a high of $13.5 \%$ in 2009 to as low as $9.1 \%$ by the end of the year 2013. During the same period, customers accessing commercial banks for financial services has grown from a low of $13.5 \%$ in 2006 to $29.2 \%$ in 2013 (Mwega, 2011). This trend in loss of customers is accredited to the rivalry from banks in the pre-emptive outreach and delivery of easy access transactions accounts as well as consumer loans through financial innovations (Fin Access, 2009).SACCOs have been losing their market share irrespective of their geographical location in the country compared to other financial institutions (Nyaga, 2012). 
International Journal of Current Aspects in Finance, Banking and Accounting, Volume 3, Issue 1, 2021 PP 9-20, ISSN 2707-8035

\section{[IJCAB}

\section{Statement of the Problem}

Despite the fact that Saccos have rapidly adopted digital financial services to provide services, and that they drive a huge section of the financial sector savings of the economy, they have experienced various challenges such as uncertainty and risk due to digital banking (Koduk, 2015). The financial performance has not necessarily gone up with such innovative technological overtures. There is a basic assumption that adoption of digital banking is a survival strategy by Saccos Subsector of engaging in technologically innovative ways of managing and running the sector to ensure sustainability (Ahimbisibwe, 2012). More than $81 \%$ of Kenyans rely on SACCO's to access financial services (Mwanahawa, 2012). However, the use of SACCOs by Kenyans as a financial service provider has been declining over the last five years. The decline has been from a high of $13.5 \%$ in 2009 to as low as $9.1 \%$ by the end of the year 2013. During the same period, customers accessing commercial banks for financial services has grown from a low of $13.5 \%$ in 2006 to 29.2\% in 2013 (Mwega, 2011). This trend in loss of customers is accredited to the rivalry from banks in the pre-emptive outreach and delivery of easy access transactions accounts as well as consumer loans through financial innovations (Fin Access, 2009). SACCOs have been losing their market share irrespective of their geographical location in the country compared to other financial institutions (Nyaga, 2012). This topic has not been adequately researched. Moreover, the correlation between digital banking and financial performance of Saccos using digital banking is still ambiguous, perhaps understandable.

Digital transactions have facilitated efficient customer centered services globally. Sathye (2005) carried a comparative study on using internet transactions banking to enhance service delivery to improve major Credit Union's financial performance in Australia. He concludes that automated transactions banking have an insignificant impact on financial performance and risk, but posits that digital transactions should be exploited as an instrument to enhance service delivery in credit unions. Mwau (2013) studied the effect of financial sector liberation in Kenya and the financial performance of Saccos. He concludes that there is no clear indication of a link between the good financial performance of Saccos and financing diversification. This study did not assess the digital banking and financial performance as digital banking may be an innovative strategy of investment. Oyugi (2014), carried out a research on the effect of automated services on performance of SASRA licensed Saccos in Nairobi and Kiambu Counties in Kenya. He concludes that there is positive effect of automation on financial performance of Saccos that adopted internet banking. This study did not link digital banking to financial performance of Saccos in Kenya.

Digital banking enhances Sacco's performance. Koduk (2015) conducted a survey study to assess the effect of digital banking on financial performance of Saccos in Nairobi County. He established a positive correlation between digital banking and financial performance of Saccos. Notably most of these studies have not been done in Western Kenya. The previous studies have mainly examined the effect of digital banking on banks' financial performance and not Saccos. The research did not link digital banking to financial performance of Saccos, in Kakamega County which has few SACCOs. The previous studies also concentrated on one year, mainly 2013. This study therefore sought to establish the digital banking services employed by SACCOs in Kakamega County and how they influenced their financial performance.

\section{Objectives of the Study}

The general objective of the study was to determine the influence of digital banking services on the financial performance of SACCOs in Kakamega County, Kenya. 
International Journal of Current Aspects in Finance, Banking and Accounting, Volume 3, Issue 1, 2021 PP 9-20, ISSN 2707-8035

ijCAB

The study was guided by the following specific objectives:

i. To evaluate the influence of mobile banking services on the financial performance of SACCOs in Kakamega County.

ii. To determine the effects of internet banking on the financial performance of SACCOs in Kakamega County.

iii. To examine the influence of credit cards on the financial performance of SACCOs in Kakamega County.

iv. To investigate the effect of digital funds transfer on the financial performance of SACCOs in Kakamega, Kenya

\section{Theoretical Review}

Theoretical framework is a collection of interrelated concepts such as in a theory to guide research work as it determines the items for measurement and the statistical relationship being studied (Kotler \& Gary, 2005). The research will be guided by three theories of innovation and technology: Diffusion of Innovation Theory, The Theory of Task-Technology Fit Theory and the Technological context, Organizational context and Environmental context Theory.

\subsection{Rogers Innovation Diffusion Theory}

Rogers's innovation Diffusion Theory (Rogers, 1995) explains how new technological innovations are accepted. This theory proposes that there are five characteristics of an innovation that affect acceptance of the innovation. The features include complexity, compatibility, testability, observability and relative advantage of the innovation. Compatibility is the extent to which an innovation is perceived as difficulty to comprehend and use. Rogers posit that the meaning of the innovation may not be understood clearly by the potential adopters or perceived as complex thereby hindering the use or adoption of the innovation (Greenhalgh, 2004). If the key users perceive an innovation as being simple to use, the innovation will be more easily adopted (Greenhalgh, 2004). Regarding digital banking, this theory is very important and applicable in modern financial services business of Saccos. Innovation is vital in order for a Sacco to improve its performance.

\subsection{Task-Technology Fit Theory}

This theory explains the matching of the abilities of technology to the demands of the job, that is, IT to support a job (Goodhue and Thompson, 1995). The theory proposes that there are four major constructs that determine IT use: Technology characteristics, Task features which jointly affect the third one, Task-Technology Fit, which later influences the outcome variable, either performance or usage. The model hypothesizes that Information technology will only be adopted if the functions necessary are accessible to the users and fit the tasks of the users. In this case, management of Saccos must act rationally to adopt IT tools and work methods that will help them accomplish the task efficiently with minimum cost and maximum net benefits.

\subsection{Technology, Organisational and Environmental Context (TOE)}

Tornatzky and Fleischer (1990), developed a clear framework that identifies three key aspects of a firm that influences the adoption process of a new technology by a firm. These aspects are Technological situation, Organizational situation, and Environmental situation. The technological situation refers to both internal and outside factors relevant to the company that can influence 
International Journal of Current Aspects in Finance, Banking and Accounting, Volume 3, Issue 1, 2021 PP 9-20, ISSN 2707-8035

iJCAB

utilisation of technology. The management of an enterprise must be aware of a number of factors and take into consideration the availability of valuable competencies. The TOE introduces a new vital component; that of the environment. The environment presents strength, constraints, opportunities, and threats for technological innovation. It is therefore vital when making a decision on whether to adopt or not to adopt and innovation such as e-banking, Saccos consider Technological, Organizational and Environmental contexts.

\subsection{Financial Intermediation Theory}

The theory regarding financial intermediation was developed starting with the 60's in the XX century, the starting point being the work of Gurley and Shaw (1960). The financial intermediation theory is based on the theory of informational asymmetry and the agency theory. In principle, the existence of financial intermediaries is explained by the existence of the following attributable factors: high cost of transaction, inadequate information in useful time; and the method of regulation. The unique factor in the studies regarding financial intermediation is constituted by the argument regarding informational asymmetry. This asymmetry can be of type: ex ante generating the so-called problem of adverse selection; concomitant generating the moral hazard(principal and agent relationship); or ex post leading to the need of applying some costly verification and auditing procedures or even the forced execution of the debtor. The informational asymmetry generates imperfections of the market, deviations from the theory of perfect markets in an Arrow -Debreu sense. Arrow-Debreu perfect markets synopsis of a near heaven, which depicts that if they is an heaven, then the financial intermediaries would not be useful in the economy at large, but since we are still on earth, it is certain that there will be imperfection and incomplete information which serve has a benefit-cost effect for intermediaries and market.

According to the model of perfect financial markets in the neo -classical theory, they fulfill the following conditions: no one participant can influence the prices; then placement/borrowing conditions are identical for all participants; there are no discriminatory fees; the lack of competitive advantages at the level of participants; all financial securities are homogeneous, dividable and transactional; there are no transaction costs for obtaining information or of insolvency; all participants have immediate aces to the complete information regarding the factors and elements that can influence the current or future value of the financial instruments. Many of these imperfections generated by informational asymmetry lead to the emergence of some specific forms of transaction costs. The financial intermediaries have emerged exactly to eliminate, at least partially, these costs. For example, Diamond and Dybvig (1983) consider banks as being a coalition of the depositors that ensures those who save up against the risks that could affect their state of liquidity. Leland and Pyle (1977) define financial intermediaries as a coalition that deals with the distribution of information. Diamond (1984) shows that these financial intermediaries action as authorized agents of those who save up and that they can achieve scale economies. Thus those who save up trust their available funds to these intermediaries in order to be invested in whichever projects they consider viable, the depositors having the possibility to withdraw their funds at any time under the pre -established conditions.

The studies regarding informational asymmetry approach especially the problematic of relationships between bank and creditors, respectively bank and debtors. In the relationship between bank and borrower the main aspect analyzed is the function of the selection bank and the tracking of the granted loans, as well as the problematic of adverse selection and moral hazard. In the relationship between bank and depositors (creditors) a special attention is given to the factors that determine depositors to withdraw their money before due date. The second approach for the 
International Journal of Current Aspects in Finance, Banking and Accounting, Volume 3, Issue 1, 2021 PP 9-20, ISSN 2707-8035

\section{[IJCAB}

financial intermediation is founded on the argument of transaction cost. This approach was developed by Benston and Smith Jr. (1976) and by Fama (1980). Unlike the first approach this one does not contradicts the theory of perfect markets. This approach is based on the differences between the technologies used by the participant. Thus intermediaries are perceived as being a coalition of individual creditors or debtors who exploit the scale economy at the level of transaction technologies. The notion of transaction cost does not comprise just the costs regarding the transfer costs for the amounts or of foreign exchange, but also those for research, evaluation and monitoring thus the role of financial intermediaries is to transform the characteristics (due date, liquidity, etc.) of assets, the so called qualitative transformation of financial assets, offering liquidity and opportunities for diversification of placements. The third approach of financial intermediaries is based on the method of regulation of the monetary creation, of saving and financing of economy. This approach was developed by Guttentag, and Lindsay (1968) and by Merton (1995). The method of regulation influences the liquidity and solvability of intermediaries. Diamond and Rajan (2000) show that the regulations regarding the capital of intermediaries influence their "health", the ability for refinancing and the method for recovering debts.

\section{Conceptual Framework}

\section{Independent Variables}

\begin{tabular}{|c|c|}
\hline \multicolumn{2}{|c|}{ Mobile banking } \\
\hline a) & Subscribers \\
\hline b) & Volum \\
\hline c) & Services and products \\
\hline d) & Rate of client uptake \\
\hline
\end{tabular}

\section{Internet banking}

a) Subscribers

b) Volume of transactions

c) Services and products

\section{Credit cards use}

a) No. of users

b) Volume of transactions

c) Services and products accessed

\section{Digital funds transfer}

a) No. of users

b) Volume of transactions

c) Services and products accessed

\section{Figure 1: Conceptual Framework}

Source: Researcher, (2021)

\section{Dependent variable}

\section{Financial performance of SACCOs \\ a) Capital adequacy \\ b) Management \\ efficiency \\ c) Earnings ability}


International Journal of Current Aspects in Finance, Banking and Accounting, Volume 3, Issue 1, 2021 PP 9-20, ISSN 2707-8035

[ICAB

A conceptual framework is a basic structure that consists of certain abstract blocks which represent the observational, the experiential and the analytical/ synthetical aspects of a process or system being conceived. It is a set of broad ideas and principles taken from relevant fields of enquiry and used to structure a subsequent presentation. The interconnection of independent and dependent variables completes the framework for certain expected outcomes. The independent variables include; mobile banking, internet banking, use of credit cards and digital funds transfer while the dependent variable is financial performance of SACCOs in Kakamega County.

\section{Research Methodology}

This research was studied using a descriptive research design. According to Cooper and Schindler (2003), a descriptive study is concerned with finding out what, where and how of a phenomenon. According to Mugenda and Mugenda (2003), a descriptive research design main aim is to evaluate and report things the way they are about the population under study, it also help to describe some of the characteristics that the researcher has no control over. The population for this study was the staff at the three SACCos operating in Kakamega County, who were 162 in number according to KUSSCO (2017) annual report and are homogenous. The target population for the study was therefore 162 respondents. The study used a semi-structured survey questionnaire administered to each member of the sample population. The questionnaire was carefully designed and tested with a few members of the population for further improvements. This was done in order to enhance its validity and accuracy of data to be collected for the study. Quantitative data collected was analyzed using descriptive statistics using SPSS (Version 22) and presented through percentages, means, standard deviations and frequencies. In addition, the study conducted a multiple regression analysis.

\section{Data Analysis Results}

Inferential statistics were determined entailing correlation coefficient, coefficient of determination (R-Square), analysis of variance as well as regression coefficients.

Table 1: Correlation Coefficient

\begin{tabular}{lccccc}
\hline & $\begin{array}{c}\text { Mobile } \\
\text { Banking }\end{array}$ & $\begin{array}{c}\text { Internet } \\
\text { Banking }\end{array}$ & $\begin{array}{c}\text { Use of } \\
\text { Credit } \\
\text { Cards }\end{array}$ & $\begin{array}{c}\text { Digital Funds } \\
\text { Transfer }\end{array}$ & $\begin{array}{c}\text { Performance } \\
\text { of Saccos }\end{array}$ \\
\hline $\begin{array}{l}\text { Mobile } \\
\text { Banking }\end{array}$ & 1.000 & 0.512 & 0.154 & 0.265 & 0.610 \\
$\begin{array}{l}\text { Internet } \\
\text { Banking }\end{array}$ & 0.512 & 1.000 & 0.199 & 0.287 & 0.568 \\
$\begin{array}{l}\text { Use of Credit } \\
\text { Cards }\end{array}$ & 0.154 & 0.199 & 1.000 & 0.401 & 0.446 \\
$\begin{array}{l}\text { Digital Funds } \\
\text { Transfer }\end{array}$ & 0.265 & 0.287 & 0.401 & 1.000 & 0.513 \\
$\begin{array}{l}\text { Performance } \\
\text { of Saccos }\end{array}$ & 0.610 & 0.568 & 0.446 & 0.513 & 1.000 \\
\hline
\end{tabular}

All the variables were found to be positively correlating to each other with performance of SACCOs having correlation index of $0.610,0.568,0.446$, and 0.513 for mobile banking, internet banking, use of credit cards, and digital funds transfer respectively. The highest correlation was 
International Journal of Current Aspects in Finance, Banking and Accounting, Volume 3, Issue 1, 2021 PP 9-20, ISSN 2707-8035

iJCAB

between mobile banking and performance of SACCOs ( 0.610) implying that the variable is a key digital banking service in determining the financial performance of SACCOs. All correlations had p-Value $<0.05$ confirming that each variable was significantly correlating with the other.

Coefficient of determination $\left(\mathrm{R}^{2}\right)$ was used to determine the extent to which explanatory variables (predictors) explained any change in the predicted variable.

Table 2: Coefficient of Determination

\begin{tabular}{clcc}
\hline $\mathrm{R}$ & $\mathrm{R}$ Square & Adjusted R Square & Std. Error of the Estimate \\
\hline 0.780 & 0.608 & 0.564 & 0.156 \\
\hline
\end{tabular}

Results in Table 4.9 show an R-Square of 0.608 with the standard error of estimate being 0.156. This implies that collectively, mobile banking, internet banking, use of credit cards, and digital funds transfer explains the financial performance of saccos up to 60.8 percent. The remaining 39.2 percent is explained by other factors that are not foreseen in this study.

Analysis of variance (ANOVA) was generated to determine the spread of the mean of variables and in particular spread between variables and spread within data.

Table 3: Analysis of Variance

\begin{tabular}{lccccc}
\hline & Sum of Squares & Df & Mean Square & F & Sig. \\
\hline Regression & 1.359 & 4.000 & 0.340 & 13.938 & 0.000 \\
Residual & $\underline{0.877}$ & $\underline{36.000}$ & 0.024 & & \\
Total & $\underline{2.236}$ & $\underline{40.000}$ & & & \\
\hline
\end{tabular}

Predictors: (Constant), Digital Funds Transfer, Mobile Banking, Use of Credit Cards, Internet

Banking

Dependent Variable: Performance of Saccos

As shown in Table 4.10, F-Calculated $(4,36)=13.938$ at 2-tail test and $95 \%$ confidence level. Results also show p-Value $=0.000<0.05$. This further confirms that at composite level, the predictors (mobile banking, internet banking, use of credit cards, and digital funds transfer) significantly influence the financial performance of SACCOs

This was done to generate a regression model as shown in Table 4.

Table 4: Regression Model

\begin{tabular}{lccccc}
\hline & \multicolumn{2}{c}{$\begin{array}{l}\text { Unstandardized } \\
\text { Coefficients }\end{array}$} & $\begin{array}{c}\text { Standardized } \\
\text { Coefficients }\end{array}$ & $\mathrm{t}$ & Sig. \\
\hline & $\mathrm{B}$ & Std. Error & Beta & & \\
\hline (Constant) & -0.017 & 0.600 & & -0.029 & 0.977 \\
Mobile Banking & 0.385 & 0.125 & 0.378 & 3.076 & 0.004 \\
$\begin{array}{l}\text { Internet Banking } \\
\text { Use of Credit }\end{array}$ & 0.195 & 0.094 & 0.257 & 2.072 & 0.045 \\
Cards & 0.230 & 0.110 & 0.239 & 2.087 & 0.044 \\
$\begin{array}{l}\text { Digital Funds } \\
\text { Transfer }\end{array}$ & 0.193 & 0.094 & 0.243 & 2.058 & 0.047 \\
Dependent Variable: Performance of Saccos & & & & & \\
\hline
\end{tabular}


International Journal of Current Aspects in Finance, Banking and Accounting, Volume 3, Issue 1, 2021 PP 9-20, ISSN 2707-8035

iJCAB

Findings as shown in Table 4 articulate that, when mobile banking, internet banking, use of credit cards, and digital funds transfer are individually increased by one unit, financial performance of SACCOs would increase by $0.385,0.195,0.230$, and 0.193 units respectively. The opposite is also true. When all the explanatory variables are held constant, financial performance of SACCOs would be at -0.017 out of 5 scores. All the predictors had p-Value $<0.05$ at $95 \%$ confidence level implying that they were all individually significant in influencing the financial performance of SACCOs. The model can be summarized as follows: $Y=-\mathbf{0 . 0 1 7}+\mathbf{0 . 3 8 5} X_{1}+\mathbf{0 . 1 9 5}_{2}+\mathbf{0 . 2 3 0 X}_{3}$ $+\mathbf{0 . 1 9 3 X}_{4}$. Where $Y$ is the dependent variable (Financial performance of SACCOs), $X_{1}=$ Mobile Banking, $\mathrm{X}_{2}=$ Internet Banking, $\mathrm{X}_{3}=$ Use of Credit Cards, $\mathrm{X}_{4}=$ Digital Funds Transfer.

\section{Conclusions}

In conclusion, the financial performance of the SACCOs was significantly influenced by the digital financial services instituted by the SACCO managements. They demonstrated to have reliable mobile banking system where most of their customers had enrolled on the mobile banking platform and most of customer queries and updates were sorted via the mobile platform. Customers also preferred using mobile banking due to its convenience to walking to the banking hall for similar services. The SACCOs also interact, update and inform clients via the internet platform where they termed the platform to be secure, reliable and convenient to clients. The SACCOs had an interactive and user friendly website and the volume of transactions via credit cards, the frequency of digital funds transfer transactions, and the volume of funds transacted on the digital transfer platform had greatly increased. Their capital adequacy, liquidity and client base had improved considerably with digital banking as well as the operational and management efficiency improvement.

\section{Recommendations}

Given the limitations and findings of this study, the researcher recommends that since there exists a positive relationship between e-banking and bank performance and e-banking has brought services closer to bank customer's hence improving banking industry performance, SACCOs must also enhance the dynamics of the sector and embrace digital banking fully and extensively. Mobile banking faces various challenges among them being, system delays by the mobile money transfer service providers, slow processing of transactions, high transactions costs, limit on the amount of money that can be withdrawn in a day and fraud. The management of the SACCOs should have an engagement and sort these issues for the betterment of their service delivery and create confidence with their customers. The SACCO management must also understand that online banking helps community banks improve their earnings ability as measured by return on equity and improve asset quality and thus the adoption of e-banking would enhance the performance of the SACCOs due to increased efficiency, effectiveness and productivity.

\section{REFERENCES}

Aduda, J. \& Kingoo, N. (2012). The Relationship between digital banking and financial performance among commercial banks in Kenya. Journal of Finance and Investment Analysis, 1(3), 99-118.

Ahimbisibwe, F. (2012). The Growth of Saccos Industry of Uganda. Uganda

Akhtar, S. Javed, Maryam, B. \& A. Sadia, H. (2012). Relationship between Financial Leverage and Financial Performance: Evidence from Fuel and Energy Sector of Pakistan. European Journal of Business and Management, 4(11), 1905-2222 
International Journal of Current Aspects in Finance, Banking and Accounting, Volume 3, Issue 1, 2021 PP 9-20, ISSN 2707-8035

iJCAB

Atavachi, B, S. (2013). Digital banking and financial performance of Deposit taking Micro finance Institutions in Kenya. Unpublished MBA project. University of Nairobi

Bascom, W. (1997). Savings and Credit Cooperative Societies Management and Supervision in Developing Financial Markets. London: Basingstoke Palgrave Macmillan.

Cooper, D. R. \& Schindler, P. S. (2006). Business Research Methods (9th ed.) New York: McGraw Hill.

DeYoung, R .P. (2000). Dictionary of Banking Terms. New York: Hauppauge

Diamond, D. \& Dybvig, P. (1983). Bank runs, deposit insurance and liquidity. Journal of Political Economy, 91, 401-419.

Diamond, D. (1991). Monitoring and Reputation: The Choice between Bank Loans and Directly Placed Debt. Journal of Political Economy, 99, 689-721.

Fama, E. F. (1980). Fama Banking in the theory of finance. Journal of Monetary Economics, 6(1),39-57.

Financial Sector Deepening Trust (FSDT), Kenya (2010). Automation of SACCOs: Assessment of Potential Solutions. 3 (2010), 1-3

Frust, K., Lang, W. \& Nolle, D., E. (20000). Internet Banking: Developments and Prospects: Office of the Comptroller of the Currency (September).

Gitau, R. M. (2011). The Relationship between financial Innovation and financial performance of Commercial banks in Kenya. Unpublished MBA Project.

Gurley, J. G., \& Shaw, E. S. (1960). Money in a Theory of Finance (No. 332.4/G97m).

Guttentag, J. M., \& Lindsay, R. (1968). The uniqueness of commercial banks. Journal of Political Economy, 71, 991-1014.

Gweyi, E. (2013). Determinants of Leverage of Savings and Cooperative Societies in Kenya. Nairobi: Acts.

Karagu, J. M. \& Okibo, B. (2014). Financial Factors Influencing Performance of Savings and Credit Cooperative Societies in Kenya, 4(2) 291-302.

Karanja, C. (2013). Effects of Financial Leverage on Financial Performance of Deposit Taking Saccos in Kenya. Nairobi: Oup.

Kariuki, B. N. (2014). The Relationship between Dividend and Financial Performance of Savings and Credit Cooperative Societies Registered by SACCO Society Regulatory Authority. Nairobi, Kenya.

Kimata, O. N. (2012). Effects of Financial Innovation on the Performance of Deposit Taking Saccos in Nairobi County. Unpublished Research project, University of Nairobi.

Koduk, S. C. (2015). The digital banking and financial performance of Savings and Credit Cooperative Societies in Nairobi County. Unpublished MBA project. University of Nairobi

Kombo, D. K. \& Tromp, L. A. (2006), Proposal and Thesis Writing, An Introduction. Nairobi: Paulines Publications Africa.

Kothari, C. (2005). Research Methodology, Methods and Techniques. New Age International Publishers. New Delhi, India.

KUSCO, (2007). The Sacco Family Union Newspaper. Nairobi, Kenya

Leland, H. \& Pyle, D. (1977). Informational Asymmetries, Financial Structure and Financial Intermediation. Journal of Finance, 32, 371-387.

Letting, N. K. (2009). The link between leadership, Strategic management and firm performance: A critical Literature Review. Unpublished PhD Independent Study Paper, University of Nairobi. 
International Journal of Current Aspects in Finance, Banking and Accounting, Volume 3, Issue 1, 2021 PP 9-20, ISSN 2707-8035

[JCAB

Mayo, H. B. (2015). Basic finance: an introduction to financial institutions, investments, and management. Ontario: Nelson Education.

Merton, R. C. (1995). Financial Innovation and the Management and Regulation of Financial Institutions. Journal of Banking and Finance, 461-482.

Mouawad, M. \& Kleiner B. (1996). New developments in Customer Service Training. Managing Service Quality, 6(2), 49-56.

Mugenda, O. \& Mugenda, A. (2003). Research Methods, Quantitative and Qualitative Approaches. Nairobi: Africa Centre for Technology Studies. Acts Press.

Mwakajumilo, C. (2011). Financial Practice as a Determinant of Growth of Savings and Cooperative Societies. International Journal of Business and Social Science, 33(24).

Neter, J., Wasserman, W. \& Kutner, M. H. (1989). Applied Linear Regression Models. Homewood, IL: Irwin.

Ngung'u, G. (2010). Orderly Movement. Business Post, 1, 28-30

Noyer, C. (2007). Financial Innovation, Monetary Policy and Financial Stability. Spring Conference. Banque de France, 21(6), 116-132.

Okiro, K. \& Ndungu, J. (2013). The Impact of Mobile Banking on Performance of Financial Institutions in Kenya. European Scientific Journal 9(13), 1857-743.

Ovia, J. (2001). Internet Banking: Practices and Potentials in Nigeria: A paper at the Conference organised by the Institute of Chartered Accountants of Nigeria.

Oyugi, C. A. (2013). The effect of Size on the financial performance of deposit taking micro finance institutions and commercial banks in Kenya. Unpublished MBA project. University of Nairobi.

Oyugi, I. G. (2014). The effect of automated service on financial performance of Savings and Credit Cooperative Societies licensed by SASRA in Kenya. Unpublished MBA Project. University of Nairobi.

Rogers, E. M. (1962). Diffusion of Innovations. New York: Free Press. 4th Edition

SASRA (2013). The Sacco Societies Regulatory Authority (SASRA). Supervision Report.. Nairobi, Kenya

Steven, A. (2000). Information Systems: Foundation of e-business. New Jersey: Prentice-Hall Inc.

Sumra, S. H., Manzoor, M. K., Sumra, H. H \& Abbas, M. (2011). The Impact of e- banking on the Profitability of Banks; A study of Pakistan Banks. Journal of Public Administration and Governance 13(1), 960-989.

Tornatzky, L. G. \& Fleischer, M. (1990). The process of technology innovation, Massachusetts, Lexington Books.

This is an open-access article published and distributed under the terms and conditions of

the cc) unless otherwise stated. Access, citation and distribution of this article is allowed with full recognition of the authors and the source. Authors seeking to publish with an Internationally Peer Reviewed Journals should consider https://www.ijcab.org/ by writing to the Editor at editor@ijcab.org or submitting online at https://journals.ijcab.org/journals/index.php. The articles must be quality and meet originality test.

$\frac{\text { IJCAB }}{\text { publishing Group }}$ 